\title{
Stability or Decline? Demand or Supply?
}

\author{
Jun SEONG Ho, JAMES B. LEWIS, AND \\ KANG HAN-ROG
}

\begin{abstract}
$\mathrm{I}_{\mathrm{a}}^{\mathrm{n}}$ $n$ the March 2008 issue of this JouRnAL, we depicted trends in the Korean economy as a period of expansion in the seventeenth century, stability in the eighteenth century, and decline in the nineteenth century. Professor Myung Soo Cha asks us to clarify whether the expanding, stable, and declining output is aggregate or per capita output and to define productivity. Reliable figures on input and output for pre-twentieth-century Korea (the primal approach) are still difficult to ascertain and generally unreliable (as acknowledged by Professor Cha). Difficulty and unreliability make a simple calculation of aggregate output still in the future. Turning to per capita output, K. J. Park and D. H. Yang heroically tried to assess the "tilled acreage per capita" from the seventeenth to the nineteenth centuries using government censuses (which they corroborated with household registers and found generally reflective of the trend) and government land surveys for taxation. They conclude, however, that a simple division of acreage by populace tells us very little unless we also consider double-cropping and "nonagricultural rural employment." Because the primal approach is not yet possible, ${ }^{2}$ Professor Cha suggests that we use the dual approach, which we have already done elsewhere, ${ }^{3}$ and which he acknowledges. He criticizes us for not repeating that approach in this JOURNAL and offers data using the dual approach to argue that, contrary to our argument, productivity declined from the seventeenth century onwards. Rather than repeat ourselves, we attempted another approach to assess productivity by looking for trends in prices.

Professor Cha questions whether it is possible to infer productivity from prices and takes issue with the factor and asset prices we published elsewhere. He argues: "the evidence on factor and asset prices indicate that the marginal productivity of land and labor declined consistently, rather than expanded, stabilized, and then declined in the precolonial centuries." We will take these points in turn.
\end{abstract}

\section{Productivity Glimpsed Through Commodity Prices}

In this JOURNAL, we sought evidence in relative prices of a Korean industrious revolution. Jan de Vries's description of an "industrious revolution" fits rather well the

The Journal of Economic History, Vol. 69, No. 4 (December 2009). (C) The Economic History Association. All rights reserved. ISSN 0022-0507.

Jun Seong Ho (Chŏn Sŏng-ho) is Guest Professor for Economic History and Korean Studies, Goethe-University, 60487 Frankfurt am Main Frauenlobstrasse 1, Germany. E-mail: SeongHo@em.uni-frankfurt.de. James B. Lewis is University Lecturer in Korean History, and Kang Han-Rog is D.Phil. Candidate in Oriental Studies, Oriental Institute, Wolfson College, University of Oxford, Pusey Lane, Oxford OX1 2LE, United Kingdom. E-mails: jay.lewis@orinst.ox.ac.uk and maggadharma@gmail.com.

Additional data supplied below is based on work supported by the National Science Foundation under Grant no. SES 0649062 (National Bureau of Economic Research).

${ }^{1}$ Park and Yang, "Standard," p. 307.

${ }^{2}$ Crafts and Harley, "Output Growth," p. 721. Even with all the work that has been done on the British Industrial Revolution, Crafts and Harley state, "Nevertheless, it is important not to overstate the degree of uncertainty." See also Antràs and Voth, "Factor Prices," p. 54 ff. By comparison, research on Korea is still in its infancy.

${ }^{3}$ Jun and Lewis, "Wages." 
circumstance we describe: "changes in relative prices, reduced transaction costs" and other commercial incentives spurred the farming family to put all its members to work to produce surpluses that could be sold in order to buy goods that the family could not produce. ${ }^{4}$ In particular, the Korean industrious revolution saw a broad, structural transformation in the roles of men and women. Men worked the fields to produce food and women produced textiles, a market good with high value, in the home. The "revolutionary" aspect of the Korean industrious revolution was not so much a change in per capita productivity, but the development of nonfood goods for market and the extensive employment of women and other family members in production for market. The Korean industrious revolution had "important demand-side features" quite unlike the supply-side character of the Industrial Revolution. ${ }^{5}$

We pursued "changes in relative prices" by pointing to a decline in cotton cloth prices and a rise in rice prices in the nineteenth century. We used rice as a proxy for food and cotton cloth as a proxy for market goods. We showed only a limited number of points for cotton cloth, because we supplied the decadal data, but in Figure 1, we now supply the 28 individual observations we have for the eighteenth century and the 26 individual observations we have for the nineteenth century. In Figure 2, we are now able to supply new data for other market goods (unginned cotton, wood fuel, lamp oil, pens and ink, and paper). We have also expanded the variety of our observations for food beyond rice (polished barley, covered barley, wheat, buckwheat, beans, and green peas) and present that data in Figure 2. The data in Figures 1 and 2 show price trends of nonfood, market goods falling from the late eighteenth century across the nineteenth century to meet rising food prices. These findings corroborate our earlier findings on labor costs, land prices, land rents, rate of return on land, and interest rates. ${ }^{6}$

In short, in the nineteenth century, the prices of market goods declined and the prices of food rose. We argue that this was because priorities shifted to obtaining food. Professor Cha asks whether this shift might be attributable to faster productivity growth in cotton textile production. Perhaps this was the case, but even when inventions appear it can take decades for technological innovation to work through to produce increased productivity and lower prices, ${ }^{7}$ and we have no indication of significant technological innovation in cotton cloth production in Korea from the eighteenth century into the 1880s. Moreover, the data supplied in Figure 2 show a general decline in prices among various market goods, not just cotton cloth. To find out why food production declined, we looked at population change, government policies to promote productivity in food production, and evidence of environmental shocks (which damaged food production).

\footnotetext{
${ }^{4}$ de Vries, Industrious Revolution, p. xi, credits the phrase to a 1986 conversation with Hayami Akira. For a recent description of Tokugawa Japan as "industrious," see Hayami, "Introduction," pp. 18-28. See also, de Vries, "Industrious Revolution," p. 256.

${ }^{5}$ de Vries, "Industrious Revolution," p. 256. French historiographical approaches to serial price runs (such as pioneered by François Simiand and Ernest Labrousse) in combination with the depiction of an organic, physiocratic, market economy by Adam Smith and the expanding attention paid to early-modern, preindustrial consumption (for example, see de Vries, Industrious Revolution) offer a promising way forward to analyse the new price data on the agricultural economy of premodern Korea. L. M. Cullen describes Simiand and Labrousse's preference for presenting long views in which "the essential changes revolved around trends in serial data on wages, prices, and rents." See Cullen, "History," pp. 636, 638-39.

${ }^{6}$ Jun and Lewis, "Wages."

${ }^{7}$ Antràs and Voth, "Factor Prices," p. 53; and Crafts and Harley, "Output Growth," p. 717.
} 


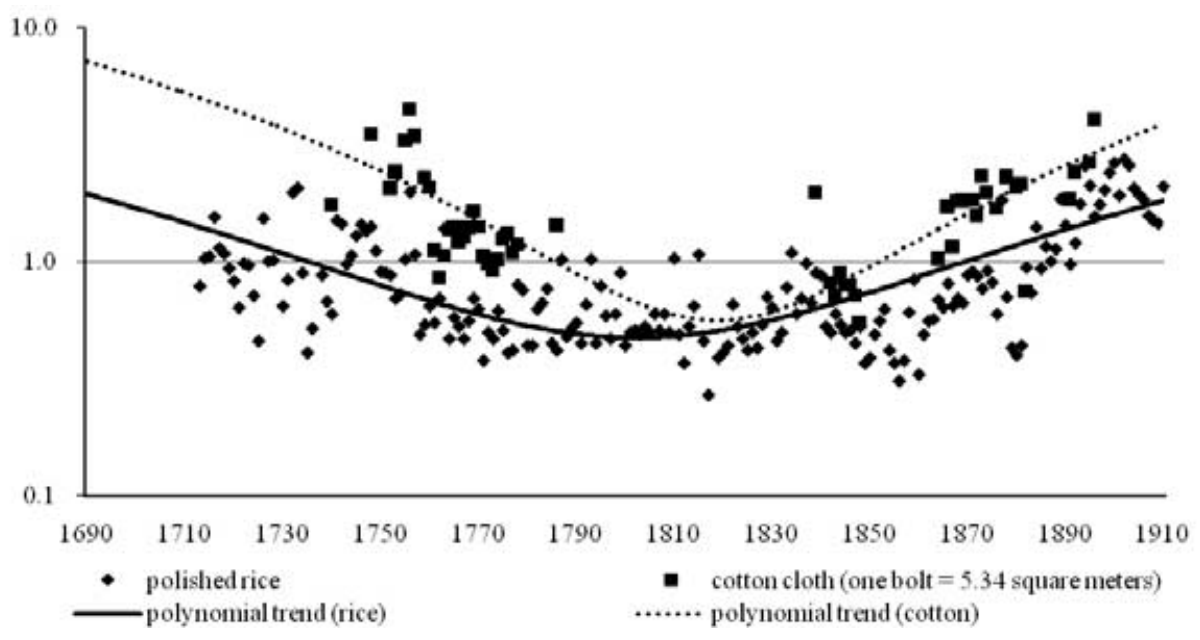

FIGURE 1

LOGARITHMIC PRICES OF RICE AND COTTON CLOTH

Note: Data has been posted online at http://www.iisg.nl/hpw/data.php (International Institute of Social History $>$ Digital Resources $>$ Historical Prices and Wages $>$ List of Datafiles $>$ Korea) and at http://gpih.ucdavis.edu./Datafilelist.htm\#Asia.

Sources: For Yŏng'am (靈岩) (South Chŏlla): Han'guk Chŏngsin Munhwa Yŏn'guwŏn, ed., Komunsŏ chipsŏng, vol. 21 and 22 (Collection of documents, vol. 21 and 22), Sŏngnam: Hanguk chŏngsin munhwa yŏn'guwŏn, 1995. For Haenam (海南) (South Chŏlla): Han'guk Chŏngsin Munhwa Yŏn'guwŏn, ed., microfilm, reel no. 35-003205-003216. For Changhŭng (長興) (South Chŏlla): Han'guk Chŏngsin Munhwa Yŏn'guwŏn, ed., microfilm, reel no. 006904. For Kosŏng (固城) (South Kyŏngsang): Süngch'ong myŏngnok (勝聰明錄). For Kyŏngju (慶州) (North Kyŏngsang): Han'guk Chŏngsin Munhwa Yŏn'guwŏn, ed., microfilm, reel no. 009574-009579. For Taegu (大邱) (North Kyŏngsang): Taegu Wǒlch'on Tanyang U-ssi munsŏ.

\section{Factor Prices: Land}

Professor Cha questions why we are looking for productivity trends in relative prices and argues that "the standard" way-in the absence of input-output data - to find productivity trends is to use a weighted average of the growth rates of land rent and labor costs. Professor Cha argues that land rents and labor costs declined from the late seventeenth century to the late nineteenth century and their declines offer no indication of the stability we mention. Let us turn to the value of land.

Elsewhere, we offered evidence on labor, capital, and land, and we found that rents declined from when our data began in 1740 to the early decades of the nineteenth century, rallied in the $1830 \mathrm{~s}$ and $1840 \mathrm{~s}$ and began to decline again in the $1850 \mathrm{~s} .{ }^{8}$ These findings generally corroborate the land rent data supplied by Professor Cha, but he pushes the onset of declining land rents back to 1685 . We would argue that land prices should also be considered as a relevant asset price, and elsewhere we have shown a general stability in land prices over the eighteenth century. ${ }^{9}$ We found that

\footnotetext{
${ }^{8}$ Jun and Lewis, "Wages," p. 239, figures 8 and 9.

${ }^{9}$ Ibid., figures 5 and 6.
} 


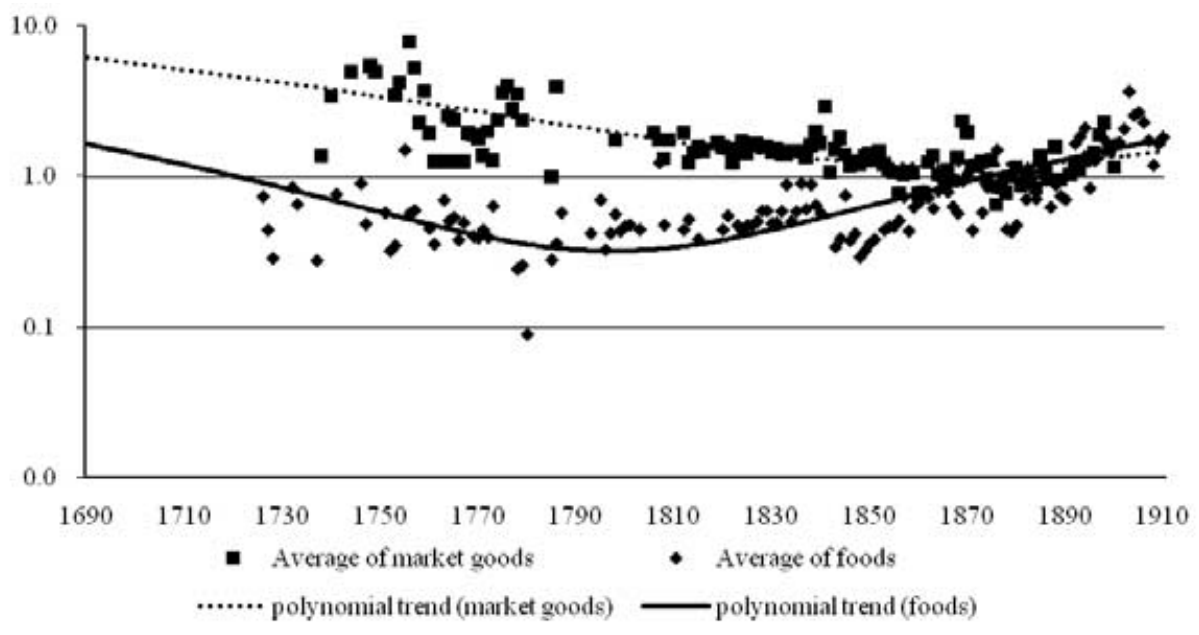

FIGURE 2

LOGARITHMIC PRICES OF MARKET GOODS AND FOODS

Note: Market goods are unginned cotton, wood fuel, lamp oil, pen and ink, and paper. Foods are polished barley, covered barley, wheat, buckwheat, beans, red beans, and green peas. Data has been posted online at http://www.iisg.nl/hpw/data.php (International Institute of Social History $>$ Digital Resources $>$ Historical Prices and Wages $>$ List of Datafiles $>$ Korea) and at http://gpih.ucdavis.edu./Datafilelist.htm\#Asia.

Sources: For Yŏng'am (靈岩) (South Chŏlla): Han'guk Chŏngsin Munhwa Yŏn'guwŏn, ed., Komunsŏ chipsŏng, vol. 21 and 22 (Collection of documents, vol. 21 and 22), Sŏngnam: Hanguk chŏngsin munhwa yŏn'guwŏn, 1995. For Haenam (海南) (South Chŏlla): Han'guk Chŏngsin Munhwa Yŏn'guwŏn, ed., microfilm, reel no. 35-003205-003216. For Changhŭng (長興) (South Chŏlla): Han'guk Chŏngsin Munhwa Yŏn'guwŏn, ed., microfilm, reel no. 006904. For Kosŏng (固城) (South Kyŏngsang): Sŭngch'ong myŏngnok (勝聰明錄). For Kyŏngju (慶州) (North Kyŏngsang): Han'guk Chŏngsin Munhwa Yŏn'guwŏn, ed., microfilm, reel no. 009574-009579. For Taegu (大邱) (North Kyŏngsang): Taegu Wŏlch'on Tanyang U-ssi munsŏ.

real land prices fluctuated in a certain range between 1740 and 1820 (stability?) and then fluctuated in a lower range thereafter (decline?). Professor Cha seems to concur by citing work that agrees with our findings. He writes that paddy field prices denominated in rice "remained stable in the eighteenth century" followed by decline in the nineteenth century. So, it seems that we all agree that land rents were declining, but the asset value of land remained stable in the eighteenth century.

\section{Factor Prices: Labor}

Professor Cha states that real wages fell in the eighteenth and nineteenth centuries. His argument is based on market wages from the late nineteenth century (that agree with our findings ${ }^{10}$ ) and on nonmarket, palace “wages" (儀軌 üigwe) from the midseventeenth century onwards. The palace wages consisted of lists of fixed prices for goods to pay labor, and these state-determined payments changed little or not at all

${ }^{10}$ Ibid., figures 3 and 4 . 
for over two centuries. Professor Cha converted these values to rice, for which we do have market prices, and concluded that wages were dropping. This is a reasonable conclusion, but we think that "wages" derived from palace records are not reflective of the labor market. ${ }^{11}$

We prefer to use market wages instead of nonmarket (palace) wages, and elsewhere we examined market wages beginning from the 1780s. To date, the only marketderived wage series that predates the early nineteenth century is the series provided by Jun and Lewis. ${ }^{12}$ Our wage data distinguishes between skilled and unskilled labor, but Professor Cha's data only mentions unskilled wages. Farm labor was generally unskilled and our findings in that regard show low, stable market wages from the 1780 s to the 1890 s (our available data). ${ }^{13}$ These findings contradict Professor Cha's findings for nonmarket wages. More importantly, though, we found a healthy gap between skilled wages and unskilled wages. We interpret this as indicating a higher standard of living for skilled labor coming out of the eighteenth century, as compared to unskilled labor. The fact that skilled wages fell to meet unskilled wages over the course of the nineteenth century shows that some sort of structural decline set in from the early decades of the nineteenth century.

To strengthen his point that real wages fell from as far back as the 1690s, Professor Cha argues that the falling prices of nobi ("slaves" or "serfs" or "servants"?) were also a sign of falling real wages. He states that "slave" prices saw a downward trend from 1689 to1893, probably even from the 1660s. In Professor Cha's Figure 2, he indeed shows that "male slave prices" fell from 1690 to the 1720 s, but then they fluctuated within a range (stability?) from around the 1720 s to about the $1850 \mathrm{~s}$. He states that a downward trend in the price of non-free (nobi) labor would have implied a fall in real wages.

Linking wage labor rates to the price of unfree labor is a complex problem. The general consensus of economic historians studying Korea is that, as the number of people working arable land increased rapidly in the late seventeenth-century recovery from the Japanese invasion (1592-1598), the need for coerced labor declined and the price of nobi collapsed, as we see in Professor Cha's Figure 2. Because rice transplantation required self-motivated, intensive peasant labor, and coerced labor carried enforcement costs, it made economic sense to lease land rather than deploy unfree workers as labor. Agricultural nobi morphed into something like "hired hands" (kogong 雇工), typical of market-oriented free labor in Korea from the fifteenth century. Agricultural nobi also morphed into tenant farmers with long-term employment contracts ${ }^{14}$ and possibly even small-scale manufacturers. Not all unfree

\footnotetext{
${ }^{11}$ Park and Yang ("Standard," p. 320) rely primarily on government wages as reported by Pak Yi-t'aek ("Seoul," pp. 41-107) to assess urban wages, which changed little between 1660 and 1885. Park and Yang and Pak make valiant efforts to calculate the fluctuating values of the in-kind portion of the wages, but the cash element remained remarkably stable. Curiously, Park and Yang found Korean urban wages paid in kgs. of rice by the government to have been about double those of Japanese urban wages in the 1880s and double those of Chinese urban wages in the eighteenth century ("Standard," p. 322). So, although these wages declined, they were still very high compared to neighboring countries. In trying to account for what they consider an anomaly, they point out that these wages were "determined by custom rather [the] market" ("Standard," p. 323), which throws into question their use as an indicator of anything aside from government policy and the health of the government fisc.

${ }^{12}$ Jun and Lewis, "Wages."

${ }^{13}$ Ibid., figure 3.

${ }^{14}$ Rhee and Yang, "Korean Nobi," p. 30.
} 
labor was to be found in agriculture. Unfree labor in Korea before 1894, when the social category was abolished, played a multitude of roles from farm labor to economic agent or steward. Nobi were one of the leading employers of hired labor among the social classes, and the workers they hired came to be predominantly women who may have been employed in cotton textile production. Unfree labor acting as stewards and employers complicates Professor Cha's depiction of nobi as competing with unskilled wage labor. In sum, the situation of "unfree" labor in the agricultural Korean economy before 1894 was economically complex and deserves further, detailed consideration, but their legal status, tax liability, and mix of functions cannot be taken as static nor as wholly economic divorced from social and political considerations. We hope that Professors Cha and Lee will pursue this problem further. ${ }^{15}$

\section{Conclusion}

Professor Cha argues that, following a devastating invasion (1592-1598), Korea saw recovery in the seventeenth century and then a general secular decline over the eighteenth and nineteenth centuries. We also find an expansionist recovery following the invasion, but we see the expansion in productivity as stabilizing in a prosperous equilibrium over most of the eighteenth century, suffering from government neglect and environmental degradation from 1800, and then declining rapidly after about 1830. To identify change in agricultural productivity for this JOURNAL, we compared grain prices to the prices of goods produced for market. We found a decline in the price of cotton cloth and a rise in rice prices in the nineteenth century. In this reply to Professor Cha's comment, we supply additional data on cotton cloth and rice and on other grain prices and the prices of other market goods to show that the shift was wider than merely rice and cotton cloth. We interpret the decline in the prices of goods for market and the rise in grain prices as indicating a shift from proto-industrial, cash crops in the eighteenth century towards foodstuffs in the nineteenth century, meaning that general productivity was declining in the nineteenth century, after having enjoyed a stable, prosperous period over the eighteenth century.

\footnotetext{
${ }^{15}$ Ch'a and Yi, "Chosŏn hugi."
}

\section{REFERENCES}

Antràs, Pol, and Hans-Joachim Voth. "Factor Prices and Productivity Growth During the British Industrial Revolution." Explorations in Economic History 40, no. 1 (2003): 52-77.

Ch'a, Myŏng-su (차명수), and Yi U-yŏn (이우연). “Chosŏn hugi e saengsallyŏk ŭn palchŏn hago issŏttna: nobi shijang ŭi chŭnggŏ (조선 후기에 생산력은 발전하고 있었나: 노비 시장의 증거, Did Productivity in the Late Chosŏn Period Develop? Evidence from the Slave Market)." Che 51 hoe Chŏnguk yǒksahak taehoe palp'yo nonmun (제 51회 전국역사학대회 발표 논문) (2008): 538-53. 
Crafts, N. F. R., and C. K. Harley. "Output Growth and the British Industrial Revolution: A Restatement of the Crafts-Harley View." The Economic History Review, New Series 45, no. 4 (1992): 703-30.

Cullen, L. M. "History, Economic Crises, and Revolution: Understanding EighteenthCentury France." The Economic History Review, New Series 46, no. 4 (1973): 635-57.

de Vries, Jan. "The Industrious Revolution and the Industrial Revolution." This JOURNAL 54, no. 2 (1994): 249-70.

The Industrious Revolution: Consumer Behavior and the Household Economy, 1650 to the Present. New York: Cambridge University Press, 2008.

Han'guk Chŏngsin Munhwa Yŏn'guwŏn (韓國精神文化研究院), ed. Komunsŏ chipsŏng (古文書集成, Collection of archival sources) Vols. 21 and 22. Sŏngnam: Han'guk Chŏngsin Munhwa Yon'guwŏn, 1995.

. Microfilm reel no. 35-003205-003216.

. Microfilm reel no. 006904.

Microfilm reel no. 009574-009579.

Hayami, Akira. "Introduction." In Emergence of Economic Society in Japan, 1600 1859: Early Modern, edited by Hayami Akira, Saitō Osamu, and Ronald P. Toby, 1-35. Oxford: Oxford University Press, 1999.

Jun, Seong Ho, and James Lewis. "Wages, Rents, and Interest Rates in Southern Korea, 1700 to 1900." Research in Economic History 24 (2007): 217-83.

Jun, Seong Ho, James Lewis, and Kang Han-Rog. "Korean Expansion and Decline from the Seventeenth to the Nineteenth Century: A View Suggested by Adam Smith." This JouRNAL 68, no. 1 (2008): 244-82.

Pak, Y. T. (박이택). “Seoul ŭi sungnyŏn mit' misungnyŏn nodongja ŭi imgŭn, 16001909: 'ŭigwe' charyo rŭl chungsim ŭro (서울의 숙련 및 미숙련 노동자의 임금, 1600-1909: 『儀軌』자료를 중심으로, Wages of skilled and unskilled labor in Seoul, 1600-1909: focusing on ŭigwe documents)." In Suryang Kyŏngjesa ro tasi pon Chosŏn hugi (수량경제사로 다시 본 조선후기, A Reexamination of the

Late Chosŏn Period Through Quantitative Economic History), edited by Yi Yŏng-hun (이영훈), 41-107. Seoul: Seoul taehakkyo ch'ulp'anbu, 2004.

Park, K. J., and D. H. Yang. "The Standard of Living in the Chosŏn Dynasty Korea in the Seventeenth to the Nineteenth Centuries." Seoul Journal of Economics 20, no. 3 (2007): 297-332.

Rhee, Young-hoon, and Donghyu Yang. "Korean Nobi in American Mirror: Yi Dynasty Coerced Labor in Comparison to the Slavery in the Antebellum Southern United States." Institute of Economic Research, Seoul National University, Working Paper Series, No. 26, 1999.

Süngch'ong myŏngnok (勝聰明錄). By Ku Sang-tŏk (具劣德 1706-1761) from Kosŏng (固城) in Kyŏngsang Province (慶少道). In Han'gukhak charyo ch'ongsŏ 7, Süngch'ong myŏngnok: 18 segi Kosŏnghyŏn ŭi nongga ilgi (韓國學 資料叢書 7, 勝聰明錄: 一八世紀 固城縣의 農家日記, 1725-1761, A Collection of archival material on Korean Studies, No. 7, Sungch'ong myŏngnok: an eighteenth-century diary kept by an agricultural household from Kosŏng), 
edited by Han'guk Chŏngsin Munhwa Yŏn'guwŏn (韓國精神文化研究院). Sŏngnam: Han'guk Chŏngsin Munhwa Yon'guwŏn, 1995.

Taegu (大邱) City, (North Kyŏngsang Province). In Taegu Wŏlch'on Tanyang U-ssi munsŏ (大丘月村丹陽 禹氏文書), edited by H. Y. Kim (金炫榮). Seoul: Han'guk komunsŏ hakhoe, 1994. 